Л. Л. Гнатишина, Г. І. Фальфушинська, Л. М. Іванець

ДВНЗ “Тернопільський державний медичний університет

імені І. Я. Горбачевського МОЗ України”

\title{
ОСОБЛИВОСТІ ОРГАНІЗАЦІЇ НАУКОВОЇ РОБОТИ СТУДЕНТІВ- ПЕРШОКУРСНИКІВ МЕДИЧНОГО ПРОФІЛЮ НА ПРИКЛАДІ РОБОТИ СТУДЕНТСЬКОГО НАУКОВОГО ГУРТКА
}

\author{
L. L. Hnatyshyna, H. I. Falfushynska, L. M. Ivanets \\ I. Horbachevsky Ternopil State Medical University \\ PECULIARITIES OF RESEARCH ACTIVITIES ORGANIZATION OF \\ FIRST-YEAR MEDICAL STUDENTS BASED ON THE ANALYSIS WORK \\ OF A STUDENT SCIENTIFIC GROUP
}

\begin{abstract}
Мета роботи - з'ясувати особливості організації науково-дослідної роботи студентів-першокурсників медичного профілю у взаємозв’язку з навчальним процесом.

Основна частина. Об’єктом даного дослідження є студентський науковий гурток (СНГ) як основна початкова позааудиторна форма організації наукової роботи. У статті розглянуто особливості організації науково-дослідницької діяльності студентівпершокурсників спеціальності “222 Медицина” на кафедрі загальної хімії ДВНЗ “Тернопільський державний медичний університет імені І. Я. Горбачевського МОЗ України” (ТДМУ).

В аспекті даного дослідження обгрунтовано доцільність використання позааудиторної форми наукової роботи на прикладі функціонування СНГ, як необхідної складової процесу формування професійної компетентності майбутнього лікаря до саморозвитку і самореалізації. У даному процесі відзначено роль куратора гуртка, як гаранта реалізації функцій СНГ, який бере активну участь у залученні студентів до наукового пошуку, аналізу наукової літератури з даної проблематики гуртка, написанні наукових звітів та обговоренні їх на засіданнях гуртка; разом із гуртківцями бере участь у науково-практичних конференціях, публікуванні та апробації результатів наукової роботи. Також значна увага приділена формуванню мотиваційного компонента у підвищенні ефективності діяльності СНГ, який поєднує використання зовнішніх та внутрішніх мотивів з домінуванням останніх.

Висновок. Для формування готовності висококваліфікованого фахівця до професійного самовдосконалення необхідно забезпечити в університетах нерозривний зв’язок навчального процесу і науково-дослідної роботи студентів у системі вищої медичної освіти, особливо на перших курсах навчання.
\end{abstract}

Ключові слова: студентський науковий гурток; мотивація; науковий потенціал; компетентнісний підхід.

The aim of the study - to clarify the peculiarities of research activities organization of first-year medical students in relationship with the educational process.

The main body. The object of this study is the students' scientific group (SSG), as the main initial extracurricular form of scientific work organization. The manuscript is shown the peculiarities of first-year medical students' research activities organization of specialty "222 Medicine” on the Department of General Chemistry at I. Horbachevsky Ternopil State Medical University (TSMU).

In terms of this study is justified the expediency of using the form of extracurricular scientific work based on the functioning of the SSG as a necessary component of the formation process of professional competence for future doctor in self-development and selfrealization. In this process it is noted the role of the curator of SSG, as the guarantor of implementation of their functions, which is actively participates in engaging students in scientific research, analysis of scientific literature, writing the scientific reports and discussing them at group meetings; together with students takes part in scientific and practical conferences, publication and validation of the results of scientific work. The role of motivational component in improving the efficiency of the SSG was noted. Last one combines the use of internal and, dominantly, external motivations.

Conclusion. For preparedness of a highly qualified specialist for professional self-improvement is necessary to provide in universities inextricable relationship of the educational process and research work of students in system of higher medical education, especially in the first years of study.

Key words: student scientific group; motivation; scientific potential; competency approach. 
Вступ. 3 урахуванням вимог щодо реалізації Національної стратегії побудови нової системи охорони здоров’я в Україні на період 2015-2025 рр., вища медична школа висуває на перший план проблему підготовки компетентних фахівців медичного профілю з достатнім рівнем професіоналізму, що базується на застосуванні компетентнісного підходу [1]. Він повинен враховувати суб'єкт-суб'єктну взаємодію викладача і студента та включати професійну, комунікативну, особистісну та науководослідницьку складову.

Вважають, що на даний час щорічно обновляється близько 5 \% теоретичних і 20 \% професійних знань [2]. Відтак, вимогами сьогодення, як однієї з необхідних умов підготовки конкурентоздатного фахівця у галузі медицини, є не тільки фахова майстерність майбутнього лікаря, але і рівень його наукового світогляду, мислення, застосування практичних підходів при насиченні знаннями, уміннями, навиками, формування компетентності до професійного саморозвитку і самореалізації [3]. Крім того, майбутній лікар повинен бути підготовлений до того, щоб постійно переробляти та інтегрувати потік інформації [4]. Тому особливу увагу слід звернути на розвиток основоположної ланки в підготовці високопрофесійних лікарів - науково-дослідної роботи (НДР) у системі модернізації вищої медичної освіти.

Питанню сутності та змісту НДР студентів у вищих навчальних закладах присвячено багато науково-методичних праць як вітчизняних, так i зарубіжних вчених [1, 4-6]. Наприклад, у практиці сучасної зарубіжної вищої школи активно застосовуються такі варіативні форми організації науково-дослідницької діяльності студентів, як: наукові пропедевтичні курси і просемінари (Німеччина); дослідні проекти (Німеччина, США, Японія); проблемно-орієнтовані курси (Англія, Німеччина, Франція); проектні технології в малих дослідних групах (США, Японія) [5].

На противагу вищеокресленим формам, у системі української освіти НДР здійснюється за такими трьома основними напрямами, як: науково-дослідна робота у навчальному процесі (впровадження результатів наукових досліджень у навчальний процес); науково-дослідна робота студентів у позааудиторний час; науково-організаційні заходи: конференції, конкурси, олімпіади тощо.

Мета роботи - 3’ясувати особливості організації науково-дослідної роботи студентів-першокурсників медичного профілю у взаємозв’язку з навчальним процесом.
Основна частина. На кафедрі загальної хімії ДВНЗ “Тернопільський державний медичний університет імені I. Я. Горбачевського МОЗ України” (ТДМУ) основною початковою позааудиторною формою організації наукової роботи є студентський науковий гурток (СНГ), у якому беруть участь студенти-першокурсники спеціальності “222 Медицина”.

Відтак, у діяльності СНГ використовуються елементи методів евристичного, дослідницького та проблемного навчання. Заняття у СНГ забезпечують не лише продовження і поглиблення навчального процесу, але й надають можливість отримати первинні практичні навички та вміння наукового експерименту [5]; сприяють залученню обдарованої студентської молоді до дослідницької творчої роботи та розширяють їх науковий потенціал. Слід зазначити, що гарантом виконання даних функцій виступає куратор гуртка, який бере активну участь у залученні студентів до наукового пошуку, аналізу наукової літератури з даної проблематики гуртка, написанні наукових звітів та обговоренні їх на засіданнях гуртка; разом з гуртківцями бере участь у науково-практичних конференціях, публікуванні та апробації результатів наукової роботи.

Можна стверджувати, що участь в СНГ є результатом студентської ініціативи, прагненням до самостійності, науково-дослідної та організаторської роботи, бажання стати кваліфікованими і успішними фахівцями, зрештою, є спробою приміряти на себе роль “науковця”, про що свідчить висока активність та регулярна відвідуваність гуртківців на кафедрі загальної хімії. Більше того, у студентів-першокурсників така зацікавленість повинна бути мотивованою, щоб дослідна робота в СНГ 3 часом переросла в активну наукову роботу на старших курсах.

Саме мотиваційний компонент не тільки забезпечує високі результати в процесі безпосереднього педагогічного впливу, але й гарантує пролонговану пізнавальну активність тих, хто навчається, у майбутньому в будь-яких життєвих ситуаціях [4].

Зокрема, одним із мотивуючих факторів для участі студентів у наукових дослідженнях є можливість залучення до наукових програм, а саме: “Студент майбутній фахівець високого рівня кваліфікації” (для студентів II-IV курсів) та “Студентська наука і профорієнтаційне навчання” (для виконання наукової роботи залучаються студенти I-VI курсів, а для участі у профорієнтаційному навчанні - студенти IV-VI курсів). Участь у даних програмах, 
окрім основних наукових цілей, надає переваги при відборі студентів на стажування, у літні міжнародні студентські школи, також створює можливість покращити рівень англійської мови тощо. Немаловажним мотивуючим чинником є підвищення особистого рейтингу студента, як успішного учасника однієї з програм.

Таким чином, внутрішнє середовище ТДМУ імені І. Я. Горбачевського створює певні зовнішні організаційні мотивуючі умови для розвитку НДР студентів. Проте найбільший ефект від даного виду діяльності студентів може бути досягнутий за наявності в них, насамперед, внутрішньої мотивації, а саме домінування мотиву досягнення, самореалізації, визнання, приналежності, статусу. Тому важливо створити умови для усвідомлення домінуючої цілі СНГ, що полягає в розвитку професійної компетентності майбутнього лікаря.

Висновки. Проведений аналіз даної проблеми, звісно, не вичерпує всіх аспектів у формуванні готовності висококваліфікованого фахівця до про-

\section{Список літератури}

1. Проблеми та перспективи вищої медичної школи у розробці та реалізації Національної стратегії побудови нової системи охорони здоров'я в Україні на період 2015-2025 pр. матеріали навч.-метод. конф., Вінниця, 25 березня 2015 р. / Вінницький національний медичний університет імені М. І. Пирогова. - Вінниця, 2015. - 255 с. - Режим доступу : http://www.vnmu.edu.ua/downloads/news/tezy.pdf.

2. “Освіта протягом життя: світовий досвід і українська практика”. Аналітична записка / Національний інститут стратегічних досліджень. - Режим доступу : http://www.niss.gov.ua/articles/252/.

3. Фролова Ф. Ф. Роль научно-исследовательской деятельности магистров в формировании компетенции профессионального саморазвития / Ф. Ф. Фролова //

\section{References}

1. Proceedings from PPHME’15: Navch.-metod. conf. "Problemy ta perspektyvy vyshchoi medychnoi shkoly u rozrobtsi ta realizatsii natsionalnoi stratehii pobudovy novoi systemy okhorony zdorov'ia v Ukraini na period 20152025 rr." - Scientific and practical conference "Problems and prospects for higher medical education in developing and implementing of National Health Reform Strategy for Ukraine for 2015-2025 yrs.”. Vinnytsia. Retrieved from http://www.vnmu.edu.ua/downloads/news/tezy.pdf [in Ukrainian]. фесійного самовдосконалення, що виявляється у відсутності розуміння єдиного механізму взаємодії різних ланок процесу здобування знань. Проте важливо усвідомити, що навчальний процес в університетах і науково-дослідна робота студентів у системі вищої медичної освіти повинні бути нерозривно пов’язані між собою. Таким чином, студентська наукова робота на перших курсах навчання у вищому медичному навчальному закладі є необхідною передумовою для отримання первинних знань в оволодінні методами наукового дослідження, формування наукового світогляду, потенціалу, творчого мислення та досягнення високого професіоналізму у майбутній професії лікаря.

У подальшому планується розглянути навчальнометодичне забезпечення науково-дослідного процесу на кафедрі загальної хімії, а також шляхи підвищення ефективності роботи студентського наукового товариства з метою активнішого залучення студентів перших курсів до дослідницької діяльності.

Вестник Казанского технологического университета. 2015. - № 17. - С. 350-353.

4. Погоріла І. О. Роль науково-дослідницької роботи студентів у фаховому становленні спеціалістів / І. О. Погоріла, О. В. Романенко // Вісник післядипломної освіти. - 2011. - Вип. 3. - С. 119-123.

5. Корчагина М. В. Анализ организации научно-исследовательской деятельности студентов в России и за рубежом / М. В. Корчагина // Вектор науки ТГУ. - 2012. № 4 (11). - С. 150-153.

6. Самсонова А. А. Роль студенческого научного общества в организации научно-исследовательской деятельности студентов вузов / А. А. Самсонова // Наукові записки кафедри педагогіки. - 2011. - Вип. 25. - С. 137-145.

2. Osvita protiahom zhyttia: svitovyi dosvid i ukrainska praktyka. Analitychna zapyska [Lifelong education: international experience and Ukrainian practice. Policy Brief] / Natsionalnyi instytut stratehichnykh doslidzhen The National Institute for Strategic Studies. Retrieved from http://www.niss.gov.ua/articles/252/ [in Ukrainian].

3. Frolova, F.F. (2014). Rol' nauchno-issledovatel'skoy deyatel'nosti magistrov $\mathrm{v}$ formirovanii kompetentsii professional'nogo samorazvitiya [The role of masters' research activity in the course of professional self- 
development competence formation]. Vestnik Kazanskogo tekhnologicheskogo universiteta - Bulletin of Kazan Technological University, 17, 350-353 [in Russian].

4. Pohorila, I.O., \& Romanenko, O.V. (2011). Rol naukovo-doslidnytskoi roboty studentiv u fakhovomu stanovlenni spetsialistiv [The role of students' research work in the professional formation of specialists]. Visnyk pisliadyplomnoi osvity - Postgraduate Education Bulletin, 3, 119-123 [in Ukrainian].

5. Korchagina, M.V. (2012). Analiz organizatsii nauchno-issledovatel'skoy deyatel'nosti studentov v Rossii i za rubezhom [The analysis of the organization of students' research activity in Russia and abroad]. Vektor nauki
Tol'yattinskogo gosudarstvennogo universiteta. Seriya: Pedagogika, psikhologiya - Vector of Science of Togliatti State University. Series: Pedagogy, Psychology, 4 (11), 150-153 [in Russian].

6. Samsonova, A.A. (2011). Rol' studencheskogo nauchnogo obshchestva v organizatsii nauchno-issledovatel'skoy deyatel'nosti studentov vuzov [The role of student science society in organization of students' research activity at higher educational institution]. Naukovi zapysky kafedry pedahohiky - Bulletin of the Department of Pedagogy, 25, 137-145. Retrieved from http://nbuv.gov.ua/UJRN/Nzkp_2011_25_19 [in Russian].

Електронна адреса для листування: gnatyshynall@tdmu.edu.ua 